\title{
Impact of Store Environment on Impulse Buying Behaviour
}

\section{INTRODUCTION}

Impulse buying is a widely prevalent phenomenon around the world. According to Coca Cola's CEO Muhtar Kent, more than $70 \%$ of Coke's sales is due to impulse purchases (Karmali, 2007). Similarly, a Canadian grocery chain observed that its profitability would increase by more than forty percent if each customer purchased an additional item on impulse (Babin and Attaway, 2000). Prior research on impulse buying found its many antecedents, including individual characteristics such as impulse buying tendency (Weun, Jones and Beatty, 1998) and optimum stimulation level (Sharma, Sivakumaran, and Marshall, 2010a); product category variables such as involvement (Jones, Reynolds, Weun and Beatty, 2003); and situational factors such as time and money availability (Beatty and Ferrell, 1998), instore advertisements (Zhou and Wong, 2003), in-store signage (Peck and Childers, 2006), instore slack (Stilley, Inman and Wakefield 2010), display (Ghani and Kamal 2010) and type of food consumed (Mishra, Mishra and Masters,2010).

On the other hand, there is a growing stream of research on store environment, which explores the influence of its various elements on consumer behavior. For example, it shows that the perceptions about store employees may influence customers' attitudes towards merchandise and service quality (Hu and Jasper, 2006). Similarly, convenience, quality, variety and value lead to positive attitudes towards private labels (Collins-Dodd and Lindley, 2003; Vahie and Paswan, 2006) and store brands (Semeijn, van Riel, and Ambrosini, 2004).

Store environment may also influence the number of items purchased, store liking, time and money spent (Sherman, Mathur and Smith, 1997), perceived quality of merchandise and patronage (Baker, Grewal and Parasuraman, 1994); sales (Milliman, 1982), product evaluation (Wheatley and Chiu, 1977), satisfaction (Bitner, 1990), and store choice (Darden, Erdem and Darden, 1983). However, there is little attention paid to the influence of store 
environment on impulse buying despite its increasing importance in making the retail “experience” a key differentiator (Hu and Jasper, 2006).

In fact, Sherman et al., (1997) explore the influence of store layout, ambience, and sales personnel on unplanned buying but not on impulse buying which is different from unplanned buying (Stern, 1962). Beatty and Ferrell (1998) proposed a model of impulse buying including some consumer traits (impulse buying tendency, shopping enjoyment tendency) and situational variables (time and money available) but do not include store-level factors. They even ask "are impulse buyers more vulnerable to store atmospherics?" Similarly, Baker et al., (2002) study the impact of store environment on patronage, but not on impulse buying.

Interestingly, Donovan, Rossiter, Marcoolyn, and Nesdale (1994) show that store atmosphere drove pleasure, time and money spent. On the other hand, Spies, Hesse, and Loesch (1997) found that a good layout reduces the "information rate" i.e. a good layout helps the consumers find products and information easily unlike a poor layout, however it is not clear to what extent store layout may encourage or inhibit impulse buying.

Recent research in the domain straddling retail store environment (and its correlates) and consumer behaviour finds that store environment is positively related to store trust and leads to more positive evaluations of merchandise (Guenzi, Johnson and Castaldo, 2009). A store perceived high on hedonic attributes provided excitement to shoppers (Ashley, Ligas and Chaudhuri, 2010). Customers look for fast and efficient billing systems, visual merchandizing, and informative signage within the store and prompt staff (Ghosh, Tripathi and Kumar, 2010). Arousal induced by music and aroma results in increased pleasure levels, which in turn positively influences approach behavior, and satisfaction with the shopping experience (Morrison, Gan, Dubelaar and Oppewal, 2011). In store marketing has a noticeable effect on visual attention (Chandon, Hutchinson, Bradlow and Young, 2009). 
Moreover, most consumer behavior is a result of both personality and situational influences (Russell and Mehrabian, 1976). While Beatty and Ferrell (1998) consider personality variables that influence impulse buying, they do not incorporate situational influences. This research includes store level situational influences on impulse buying in our model. There has been research on a few personality variables explaining impulse buying (Rook and Fischer, 1995; Ramanathan and Menon, 2006; Baumeister, 2002) and a few individual store-level variables' influence on impulse buying (Peck and Childers, 2006; Spies et al., 1997; Zhou and Wong, 2003).

From the review of past and recent literature, it is clear that there is no comprehensive model that links both personality and situational variables with impulse buying. This paper attempts to come out with a comprehensive model that incorporates both to explain impulse buying, philosophically in line with Russell and Mehrabian (1976). Specifically, this paper addresses this major gap in extant literature by studying the impact of four elements of store environment (music, light, layout, and employees) along with two individual characteristics (impulse buying tendency and shopping enjoyment tendency) on impulse buying behavior. In line with prior research, we included positive and negative affect (Beatty and Ferrell, 1998), and the urge to buy impulsively (Dholakia, 2000) as mediators of the influence of store environment and individual variables on impulse buying behavior.

\section{CONCEPTUAL FRAMEWORK AND HYPOTHESES}

Impulse buying, according to Beatty and Ferrell (1998) is "a sudden and immediate purchase with no pre-shopping intentions either to buy the specific product category or to fulfill a specific buying task" whereas unplanned reminder buying may simply be 'out of stock' reminder buying. Impulse buying is thus a spur-of-the-moment purchase with little thought (a shopper sees some candy and decides to buy on a sudden urge) while unplanned reminder buying is buying since the shopper forgot to put an item on her list (a shopper sees 
sugar in the store, remembers she is out of stock and buys it). Thus, our definition taken from Beatty and Ferrell (1998) would include only genuinely "impulsive" purchases. This section proposes a holistic model of impulse buying with four elements of store environment and two individual characteristics (impulse buying tendency and shopping enjoyment tendency) as antecedents of impulse buying.

\section{Store Environment}

Store environment consists of ambient factors such as lighting, scent, and music; design factors such as layout and assortment; and social factors such as the presence and effectiveness of salespersons (Baker et al., 2002). Layout refers to the way in which products, shopping carts, and aisles are arranged; the size and shape of those items, and the spatial relationships among them. Product assortment is the total set of items offered by a retailer. Social factors refer to the people such as other shopper and salespeople (Baker et al., 2002). Other shoppers were not considered in this study as this was not directly under the control of the retailer (unlike all the other factors that were considered).

Ward et al. (1992) state that consumers do not perceive a store in piecemeal fashion and it is the total configuration of cues (the gestalt of consumers' perceptions of store) that influences their responses (Mattila and Wirtz, 2001). However, most prior studies do not operationalize store environment as an overall construct and instead explore the influence of individual elements of store environment, such as layout and signage (Ang, Leong and Lim, 1997), product assortment (Simonson, 1999), ambience, and salesperson availability (Sharma and Stafford, 2000), music (Dubé and Morin 2001, Beverland et al. 2006), lighting (Summers and Hebert, 2001), and scent (Mattila and Wirtz, 2001, Chebat and Michon, 2003). In fact, Baker et al., (2002) include multiple cues (employee, design and music perceptions) in a single study; however they also study the individual impact of these variables and not the overall effect of store environment. Therefore, this paper defines store environment as a 
perception of the combination of its elements namely music, lighting, layout and employees. We consider its overall impact on customer perceptions and behavior.

\section{Positive and Negative Affect}

Affect is a valenced feeling state characterized by its two orthogonal dimensions, namely positive and negative affect (Watson, Clark and Tellegen, 1988). Sherman et al., (1997) suggest that cognition affects store choice whereas emotion affects unplanned purchases. Emotions produced in-store relate with unplanned buying (Donovan et al., 1994) and impulse buying (Rook, 1987). Shoppers come to stores with specific goals and constraints and affective reactions occur as they work towards meeting such goals (Machleit and Eroglu, 2000). In this paper, we only consider the affect induced in response to the various elements of the store environment and not the pre- or post-shopping affective states.

Positive affect represents the extent to which a person may feel enthusiastic, active, and alert (Beatty and Ferrell, 1998, pp. 172). High positive affect is a state of high energy, full concentration, and pleasant engagement; whereas low positive affect may consist of sadness and lethargy (Watson, Clark and Tellegen, 1988). In contrast, negative affect involves a feeling of distress and non-pleasurable engagement that subsumes a variety of aversive affective states, such as anger, disgust, guilt, fear, and irritation (Watson et al. 1988).

\section{Store Environment and Positive Affect}

Shoppers respond to music psychologically and behaviorally (Yalch and Spangenberg, 1990). Music is an important, frequently and commonly studied variable that influences affective states (Bruner, 1990). It is a key ambient variable (Bitner, 1992) shaping consumer behavior in retail environments (Milliman, 1982; 1986; Yalch and Spangenberg, 1990). The presence of pleasant music produces positive affect (Garlin and Owen, 2006). Well-designed lighting systems can bring an added dimension to an interior, guide the customer's eyes to key 
sales points, create an atmosphere of excitement and induce positive affect (Smith, 1989). Lighting and music together evoke positive affect (Yoo, Park and MacInnis, 1998).

Positive experiences arise if the store makes it easy for the consumers to find the product they are looking for, by providing a logical store layout and sufficient signage (Bitner, 1992; Spies et al., 1997). Retail layouts are important since they help present product assortments in an effective and positive way (Aghazadeh, 2005). A good layout may produce and enhance positive affect by helping the shoppers find what they want faster (Spies et al., 1997). A good layout may also make the shopping more enjoyable, by reducing the perceived stress in shopping (Baker et al., 2002) and by evoking positive affect (Yoo et al., 1998).

Store personnel contribute to entertaining store experiences (Jones, 1999). Employee responses can significantly influence important consumer responses (Bitner, 1990). Often, subtle aspects in the personnel's behavior contribute to positive feelings, for e.g. a smile or easily being available for the consumers. Even in brief and mundane encounters the employee induces positive affect (Mattila and Enz, 2002). Retail stimuli biases affect evaluation in an affect-congruent direction (Gardner, 1985). Based on the above discussion, we posit,

H1: Higher evaluations of store environment lead to higher levels of positive affect.

\section{Store Environment and Negative affect}

Loud music is one of the major irritants of shopping (D'astous, 2000). Improper or loud music may cause physical discomfort (Bitner, 1992) and may induce negative affect. In attempting to create an "appropriate" (i.e. soft lighting) atmosphere, management may adopt a lighting scheme that inhibits shoppers from examining the merchandise, inducing negative affect. Improper illumination levels reduce visual acuity that is needed to complete environmental tasks (Areni and Kim, 1994). Cluttered shelves, narrow and irregular aisles may increase consumers' perception of crowding which in turn may lead to negative affect. A poor layout causes negative affect (Spies et al., 1997, Jones, 1999). 
At the retail outlet, affect is induced by the salesperson (Gardner, 1985; Yoo et al., 1998). A salesperson's actions and behaviors can influence customer satisfaction with him/her as well as the retailer (Oliver and Swan, 1989) and customer satisfaction has an affective basis (Westbrook and Oliver, 1991). This linkage occurs, at least in part, because the salesperson and selling firm are often indistinguishable in the mind of the shopper (Crosby et al., 1990). In fact, absence of salespersons or bad salesmanship may also cause negative affect (Jones, 1999). This leads to:

H2: Lower evaluations of store environment lead to higher levels of negative affect.

\section{Store Environment and Urge to Buy Impulsively (Urge)}

Urge to buy impulsively (urge) is a state of desire that is experienced upon encountering an object in the shopping environment such as a specific product, model or brand (Rook, 1987, Dholakia, 2000). It is spontaneous, sudden and clearly precedes the actual impulse action (Beatty and Ferrell, 1998). As consumers browse around in a store, they experience more and more urges, and their likelihood of engaging in an impulse purchase increases (Beatty and Ferrell, 1998).

Music is an important non-verbal communication, generally used to enhance store atmosphere and sometimes it may induce unplanned (Turley and Milliman, 2000) and even impulse buying (Mattila and Wirtz, 2001). Music makes people stay longer, spend more time and money than normal (Milliman, 1982; 1986); hence it is likely that some of this spending may be unplanned and possibly result in impulse buying. In fact, music and lighting are important triggers that create an urge to purchase impulsively (Eroglu and Machleit, 1993). Music also influences shoppers' pleasure and satisfaction (Morrison et al. 2011).

Good lighting techniques help create the right ambience (as in a restaurant). A store with appropriate lighting may entice shoppers to experience the store and create an urge to purchase. Well-designed lighting systems can bring an added dimension to an interior, guide 
the customer's eyes to key sales points, create an atmosphere of excitement, induce positive affect, or simply make key approach areas safe and visible (Smith, 1989). Ambient factors including music and lighting have a positive effect on arousal (Sherman et al., 1997) and all these can trigger a desire (urge) to purchase impulsively (Eroglu and Machleit, 1993).

An optimal layout gives the ability to facilitate the access to information and aids the shopper in decision-making. Peg boards and end caps induce urge to buy impulsively (Aghazadeh, 2005). A good layout makes even the utilitarian shopper to buy additionally by creating an urge in them (Sherman et al., 1997). Salespersons can guide the consumer to explore the store and the product range, thereby inducing the urge to buy impulsively. Hence,

H3: Higher evaluations of store environment lead to higher levels of urge to buy impulsively.

\section{Shopping Enjoyment Tendency and Positive Affect}

Shopping enjoyment tendency is defined as the pleasure one obtains in the shopping process (Beatty and Ferrell, 1998). Shoppers derive joy and pleasure from shopping (Babin, Darden and Griffin, 1994). People shop for both hedonic and utilitarian reasons (Jones, 1999), Consumers who enjoy shopping engage more in non-planned purchases, and get a great deal of psychological rewards by shopping process per se (Bellenger and Korgaonkar, 1980). Based on the above and in line with Beatty and Ferrell (1998), we hypothesize:

H4: Higher levels of shopping enjoyment tendency lead to higher levels positive affect.

\section{Impulse Buying Tendency (IBT)}

Broadly in line with Weun et al., (1998) and Beatty and Ferrell (1998), we define impulse buying tendency (IBT) as the tendency to make unplanned purchases and to buy spontaneously, with little or no deliberation or consideration of the consequences. Consumers with higher IBT score are more likely to experience impulsive urges and to buy impulsively in a retail store (Beatty and Ferrell, 1998). Therefore, 
H5: Higher levels of impulse buying tendency lead to higher levels of urge to buy impulsively

\section{Positive Affect and Urge to Buy Impulsively}

Prior research shows a positive association between positive affect and impulse buying. Donovan et al., (1994) found that a pleasant environment contributed to extra time and unplanned shopping as it increases impulsive urges. Beatty and Ferrell (1998) also found a positive relationship between positive affect and urge to buy impulsively. Hence, we posit, H6: Higher levels of positive affect lead to higher levels of urge to buy impulsively

\section{Negative Affect and Urge to Buy Impulsively}

The effect of negative effect on impulse buying is ambiguous in the literature. One line of research shows that stress reaction (Youn and Faber, 2000) and self gifting are used to relieve depression (Mick and DeMoss, 1990) i.e. this suggests that negative affect would have a positive effect on impulse urges. In a retail setting, negative affect generally creates a desire to withdraw from an environment as it makes the consumer perceive that the store is not likely to solve his/her intended purpose for visiting it (Eroglu and Machleit, 1993). Hence, there is little chance of impulsive urges being generated. In line with prior research, we assume that positive and negative affect are orthogonal to one another (Watson and Tellegen 1985, Beatty and Ferrell 1998, Silvera, Lavack and Kropp 2008).

Moreover, Youn and Faber (2000) talked about pre-existing negative effect ("I feel low, so will buy something and perk up") and not store-induced affect, which is what we are concerned with in this paper. Since negative affect may cause withdrawal from the store, it is unlikely to lead to impulsive urges. Hence, the following:

H7: Higher levels of negative affect lead to lower levels of urge to buy impulsively. 


\section{Urge to Buy Impulsively and Impulse Buying}

Finally, prior research shows that consumers continuously experience impulsive urges during their shopping trips as they browse around the stores (Rook, 1987; Beatty and Ferrell 1998), and they are unable to resist many of these impulsive urges despite their best efforts to control or regulate them (Dholakia, 2000; Baumeister, 2002). Therefore, as argued earlier, we hypothesize a positive relationship between the urge to buy impulsively and impulse buying.

H8: Higher levels of urge to buy impulsively lead to higher levels of impulse buying.

Figure 1 summarizes all the hypotheses.

$<$ Insert figure 1 about here $>$

\section{METHODOLOGY}

\section{Sample}

We used a single-stage mall-intercept survey method to collect data using a process similar to previous studies (e.g., Beatty and Ferrell, 1998; Sharma, Sivakumaran and Marshall, 2010a) in Chennai, a city in South India. A leading Indian supermarket chain gave us permission to conduct our survey in its 44 outlets in different shopping locations within Chennai, to provide a fair representation of different segments of shoppers.

A total of 1478 shoppers were approached out of which 733 agreed to participate in the study, and after removing 13 incomplete questionnaires we had a usable sample of 720 ; a reasonably high response rate of about $49 \%$. The respondents were told that this survey was a part of a student project from a prestigious university in Chennai and possibly this account for the good response rate despite not paying any compensation to the participants. The sample has almost similar proportions of males (52\%) vs. females (48\%), and married (51\%) vs. unmarried (49\%) participants. The average age is about 30 years and most participants have a high school education and above (85\%), representing occupations such as students 
(26\%), housewives (19\%), self-employed (13\%), employed (39\%), and retired (3\%). Overall the sample fairly represents the target population of urban adult Indian shoppers.

\section{Measures}

We measured all the independent and mediator variables with multiple-item scales used in past research (except for lighting) after pre-testing these scales along with several others in a series of studies with shoppers. To measure lighting, we adapted items from three existing scales. Table 1 shows all the scale items, their sources, and the relevant descriptive statistics for each item. First, we measured the dependent variable, impulse purchases always. Then, we measured store related variables, then the mediators (positive and negative affect and urge) and then the trait variables (IBT, Shopping enjoyment tendency) and then the demographics. After measuring the dependent variable, impulse purchases, we counterbalanced questions within each category (for example, questions pertaining to the store environment, mediators and trait variables).

$<$ Insert table 1 about here $>$

\section{Procedure}

The interviewers were twenty undergraduate students of a Research Methodology class who received partial course credit for participation in the project. One of the authors trained all interviewers on understanding the questionnaire, how to approach the shopper, answering doubts, measuring impulse purchases, how to close the interview and other aspects of the survey, in line with Dillman (1994) and Beatty and Ferrell (1998).

The interviewer intercepted the shoppers upon their exit from the store and requested their participation in our survey. Having recorded all the purchases made by each participant, (s)he asked the shoppers whether each of these purchases was planned or unplanned. Out of all the unplanned purchases, the reminder type items were eliminated by the following question: "When you saw this item, were you reminded that you were out of this item and 
needed it?" (S)he recorded as impulse purchases only those that were clearly unplanned and could not be classified as reminder items (Beatty and Ferrell, 1998). One of the researchers counted the number of such purchases for each shopper to arrive at a total number. Overall, this survey found around $16 \%$ of total purchases to be pure impulse buys while $6.4 \%$ were reminder based unplanned purchases. Table 2 shows the frequency distribution of the total number of impulse purchases by each shopper.

$<$ Insert table 2 about here $>$

Besides the 'total number of items bought on impulse' we used the 'proportion of items bought on impulse' as another operationalization of our dependent variable. However, for data with a wide range of 'whole' numbers log transformations are recommended (Steel and Torrie 1980). Moreover, for data using proportions or percentages, the variance of means tends to be smaller near $0 \%$ and $100 \%$ compared to the means near $30 \%$ to $70 \%$, and arcsine transformation is recommended to address this concern (Steel and Torrie 1980). Hence, for a more rigorous analysis, our dependent variable was transformed using log and arcsine transformations. No major differences in the model fits, the path coefficients, and their levels of significance were found.

Since many participants did not buy on impulse (58.5\%) and only a few bought more than 3 items on impulse (5.3\%), we also tested for the impact of outliers on our findings. For this, we eliminated the top $10 \%$ and the bottom $10 \%$. We did not find major differences between the fit and the path coefficients that were originally obtained. We also compared the average scores for all the variables (store environment-related, trait-related, urge-related, affect-related and impulse purchases-related) and their relationships with each other across different groups based on demographic variables and found no major differences. Hence, we do not discuss these any further.

\section{DATA ANALYSIS AND FINDINGS}




\section{Measurement Model}

We used a two-stage structural equation modeling approach with AMOS 17.0, first testing the measurement model before analyzing the structural one (Anderson and Gerbing, 1988). Based on prior research on reflective vs. formative measurement models (e.g., Diamantopoulos and Winklhofer, 2001; Jarvis, Mackenzie and Podsakoff, 2003; Coltman et al., 2008), we treated shopping environment as a second order formative construct with four elements (i.e., music, lighting, employees, and layout) as formative indicators since shopping environment does not exist as an independent entity independent of these four elements; rather, it is a composite measure of these four elements. We treated store environment as a formative second order factor construct since a priori there is no reason to believe that lighting, music, layout and employees would be correlated with one another and that they would be driven by store environment, a second order factor. Rather, it makes much more conceptual sense to think of the perception of store environment being influenced by perceptions of lighting, music, layout and music. This is also consistent with Jarvis et al. (2003) who advocate using a formative model under such conditions.

Except for assortment and scent, we obtained excellent reliabilities for all constructs. Hence, assortment and scent were dropped from further data analysis. After assessing the individual reliability of the constructs, the measurement model shows a good fit even without adding error covariances $\left(\chi^{2}=398.68, \mathrm{df}=137, \chi^{2} / \mathrm{df}=2.91, \mathrm{RMSEA}=.051, \mathrm{SRMR}=.063\right.$, $\mathrm{CFI}=.96)$ with all the fit-indices better than the recommended $(\mathrm{RMSEA}<.06, \mathrm{SRMR}<.08$, CFI > .95) cut-off values (Hu and Bentler, 1999; Wheaton et al., pp 102, 1977).

To test the convergent validity of our measures, we examined the parameter estimates and found them to be large (>.65) with significantly large t-values (15.9 to 23.8) (Anderson and Gerbing, 1988) with high values of item-to-total correlations (0.40 to 0.72$)$ and average variance extracted (0.47 to 0.71$)$ showing high convergent validity (Fornell and Larcker, 
1981). All the measures also show discriminant validity as the average variance extracted in each factor exceeds the square of its correlations with all the other constructs (Fornell and Larcker, 1981).

\section{Common Method Variance}

Since this study uses the predictor and criterion variables from the same source in a single survey, we took several precautions to minimize the impact of common method variance (CMV). Specifically, we did not collect any personal information from the participants to reduce socially desirable responding and evaluation apprehension by ensuring the anonymity of the responses. The survey also used a Likert format for the independent variables and directly calculated the value of the dependent variable, reducing "method bias due to the commonalities in scale endpoints and anchoring effects" (Podsakoff et al., 2003).

Using the above procedural remedies helped us minimize CMV in this study but it may not have been eliminated completely and it is also difficult to identify its exact source(s). Although Harman's (1967) single-factor test is a popular choice to address this, it is an 'insensitive' test, which is likely to under-identify the sources of CMV and it may not control (or partial out) method effects (Podsakoff et al. 2003). Hence, to estimate the method biases at the measurement level and to control the measurement error, we used the 'single-commonmethod-factor' approach (Podsakoff et al., 2003).

Specifically, we compared the fit indices between our original measurement model and one in which all the items loaded on a latent CMV factor besides their theoretical constructs. This method allows the partitioning of the variance of responses to a specific measure into three components: trait, method, and random error. The model with the CMV factor showed a poor fit $\left(\chi^{2}=879.13, \mathrm{df}=166, \chi^{2} / \mathrm{df}=5.29, \mathrm{RMSEA}=.092, \mathrm{SRMR}=.181\right.$, $\mathrm{CFI}=.77)$, and a significantly higher $\chi^{2}$ value compared to the original measurement model $\left(\Delta \chi^{2}=480.45, \Delta \mathrm{df}=29, \mathrm{p}<.001\right)$. Hence, most of the variance in this data is explained by the 
individual constructs and common method variance does not seem to be a significant problem in this study (Podsakoff et al., 2003).

\section{Structural Model}

The structural model had a good fit $\left(\chi^{2}=388.52, \mathrm{df}=155, \chi^{2} / \mathrm{df}=2.51, \mathrm{RMSEA}=\right.$ $.045, \mathrm{SRMR}=.056, \mathrm{CFI}=.95)$ with all the fit-indices better than the recommended cut-off values $(\mathrm{RMSEA}<.06, \mathrm{SRMR}<.08, \mathrm{CFI}>.95)$. Due to the dependency of the $\chi^{2}$ statistic on the sample size, a higher than cut-off value of comparative fit index (CFI) and a value of the $\chi^{2} / \mathrm{df}$ less than three indicate a good fit (Kline ,1998). Other fit indices (NFI $=.94$, AGFI $=$ .92) are also high, showing a good fit. The analysis revealed support for all our hypotheses except for the effect of negative affect on urge (H7) as summarized in Table 3.

$<$ Insert table 3 about here $>$

Specifically, the results indicated that the overall perception of store environment exerts a significant positive effect on positive affect $(\beta=.31, \mathrm{p}<.01)$ and has a significant negative influence on negative affect $(\beta=-.29, \mathrm{p}<.01)$, supporting $\mathrm{H} 1$ and $\mathrm{H} 2$ respectively. In addition, overall perception of store environment has a positive effect on the urge to buy impulsively $(\beta=.15, \mathrm{p}<.05)$, supporting H3. Moreover, shopping enjoyment tendency has a positive effect on positive affect $(\beta=.11, \mathrm{p}<.05)$ and impulse buying tendency has a positive impact on the urge to buy impulsively $(\beta=.45, \mathrm{p}<.01)$, thus supporting $\mathrm{H} 4$ and H5 respectively. Positive affect has a positive influence on the urge to buy impulsively $(\beta=.27 ; \mathrm{p}$ $<.05)$, supporting H6. However, the effect of negative affect on urge to buy impulsively is not significant $(\beta=-.01 ; \mathrm{p}>.10)$; thus $\mathrm{H} 7$ is not supported. Finally, as expected, the urge to buy impulsively has a positive effect on impulse buying $(\beta=.27 ; \mathrm{p}=<.01)$, supporting H8.

Test of Urge as a Mediator: We tested the mediating role of urge using the method proposed by Iacobucci, Saldanha, and Deng (p.152, 2007) by first testing a model with a direct path from store environment, positive affect, and negative affect to impulse buying, 
and an indirect path via urge. This model also showed a good fit $\left(\chi^{2}=405.50, \mathrm{df}=152, \chi^{2} / \mathrm{df}\right.$ $=2.67, \mathrm{RMSEA}=.048, \mathrm{SRMR}=.059, \mathrm{CFI}=.94)$. None of the path coefficients for the direct effects are significant, whereas those for the indirect effects are all significant (as shown in Fig. 2). Hence, there is evidence of some mediation (Iacobucci et al. 2007).

$<$ Insert figure 2 about here $>$

Next, we explicitly tested the relative sizes of the indirect (mediated) vs. direct paths by calculating the $\mathrm{z}$-value using the formula: $\mathrm{z}=(\mathrm{a} * \mathrm{~b}) /\left(\mathrm{b}^{2} \mathrm{~s}_{\mathrm{a}}{ }^{2}+\mathrm{a}^{2} \mathrm{~s}_{\mathrm{b}}{ }^{2}\right)^{1 / 2}$, where $\mathrm{a}(=.16)$, is the unstandardized regression coefficient for the association between the independent variable $\left(\mathrm{IV}=\right.$ store environment) and the mediator (urge) and $\mathrm{s}_{\mathrm{a}}(=.05)$ is the standard error of a. Similarly, b (=.30) is the unstandardized regression coefficient for the association between the mediator (urge) and the dependent variable (DV = impulse buying) when the independent variable (store environment) is also included as a predictor in the model. $\mathrm{S}_{\mathrm{b}}$ $(=.07)$ is the standard error of $b$. Using the above formula, a significant $\mathrm{z}$-value $(2.56, \mathrm{p}<.01)$ was obtained, which means that the indirect effect of the IV (store environment) on the DV (impulse buying) via the mediator (urge) is significantly different from zero. These findings support a full-mediation model (Iacobucci et al. 2007).

$<$ Insert table 4 about here $>$

The correlations matrix of all possible pair-wise inter-correlations of all the variables in the model (Table 4) also supports the relative superiority of the mediated vis-à-vis nonmediated or partially mediated models. Specifically, the correlations for music, light, employees, and layout with urge $(.16, .27, .30$, and -.11 respectively) are stronger than those with impulse buying $(.02, .08,-.00$, and -.04 respectively). Moreover, urge and impulse buying are also positively correlated (.14). Hence, the four elements of store environment seem to have a stronger and direct influence on urge, which in turn has a positive effect on impulse buying, as confirmed in our mediation analysis as well. When the model was re-run 
without urge, its fit was poor. This shows that it is important to have urge in the model, as also recommended by Beatty and Ferrell (1998).

\section{DISCUSSION}

Data analysis found a good fit for our model and obtained support for all hypotheses except one. Specifically, it was found that store environment drives impulse buying behavior through impulsive urge. However, we did not find any influence of negative affect on the urge to buy impulsively; the reason for this in explained in a separate sub-section.

Our research makes a number of theoretical contributions. Sherman et al., (1997) explored the influence of store layout, ambience, and sales personnel on unplanned buying but not on impulse buying which is different from unplanned buying (Stern, 1962). While Beatty and Ferrell (1998) came up with model that explains impulse buying, they did not consider store level variables. It is important to do so since a very high percentage of shopping decisions are taken in the store (Peck and Childers, 2006; Underhill, 1999; Zhou and Wong, 2003). According to Coca Cola's CEO Muhthar Kent, the point of sale (store) is critical as more than seventy percent of Coke's sales is based on impulse purchases (Karmali, 2007). A Canadian grocery chain exploring the avenues for increasing profitability had observed that if each customer purchased one additional item, profitability would increase by more than forty percent (Babin and Attaway, 2000).Hence, by extending Beatty and Ferrell (1998) in this manner, our research makes an important contribution to the literature. Our study thus addresses this major gap in extant literature by studying the impact of four elements of store environment (music, light, layout, and employees) along with two individual characteristics (impulse buying tendency and shopping enjoyment tendency) on impulse buying behavior. Earlier studies have considered the various store environment variables on the shoppers' behavior independently, but have not taken the gestalt approach. In sum, this paper offers a comprehensive model of impulse buying including individual 
characteristics as well as store environment, as it considers both store and trait characteristics together (Russell and Mehrabian, 1976) Another aspect that is new in this model is that store environment is not just a standard second order construct, but as a formative one, in line with the recommendations of Jarvis et al. (1993).

Likewise, we extend Baker et al (2002) by showing that store environment influences not only patronage but also impulse buying. Moreover, extant literature shows the long term effects of store environment such as store choice (Darden et al.1983), whereas this research show that it has immediate and spontaneous behavior on immediate and spontaneous effects such as impulsive buying. It also add to the findings of Donovan et al., (1994) and Spies et al. (1997) by showing that store environment affects not just unplanned purchasing (that may be due to more in-store search or developing an affect-based liking to a product), but pure impulse buying as well, which is a result of spontaneous impulsive urges.

Lack of Support for H7: We did not find support for H7. i.e. negative affect did not affect urge to buy impulsively negatively. Beatty and Ferrell (1998) also did not find a significant influence of negative affect on urge to buy impulsively. The reason for this could be that shoppers could not distinguish clearly between pre-existing negative affect that may possibly lead to higher impulse buying (e.g., Youn and Faber, 2000) and negative affect that arises as a result of a poor shopping trip that should lead to lesser impulsive buying. Measurement of affect is fraught with problems in survey research; hence further research using alternate methods to measure affect may clarify the effect of negative affect.

\section{MANAGERIAL IMPLICATIONS}

This research also has many important managerial implications. First, the results found that roughly $16 \%$ of shoppers' purchases were on impulse in our study. This shows that at least in our sample of Indian shoppers, we found that impulse buying was prevalent, though not to the extent that it is in other (especially Western) countries. Since the results 
were obtained in India, we believe that the results are generalizable to most other countries, especially Western ones. This is because in India, most stores are small, by Western standards. Most stores have an area of only 2000 sq. feet or so. This means that aisles are cramped. There are frequent power outages leading to air conditioning being turned off, there are only a few check-out counters and so on. If impulse buying is generated here because of store environment, surely it ought to be engendered in other countries where stores are larger, nicer with better ambience and so on. Finally, impulse buying is considered normatively wrong and likely to be understated, especially in a collectivist country like India (Kacen and Lee, 2002; Tuyet Mai et al., 2003). Thus, ours is a conservative test.

We calculated direct, indirect and total effects of all variables on impulse buying. For instance, from the path coefficients in Figure 2, the total effect of light on IB was 0.029 $\{(.2 * .32 * .02)+(.2 * .16 * .3)+(.2 * .32 * .25 * .3)+(.2 * .08)+(.2 *-.27 * .06)+(.2 *-.27 *-$ $.03 * .3)=0.029\}$. All these effects are reported in Table 5 .

$$
<\text { Insert table } 5 \text { about here }>
$$

We found that among all the store environment elements, layout had the highest effect on impulsive buying. This is an interesting finding because until recently most Indian retail outlets tended to be small and cramped with little access for the shoppers to the actual merchandise. However, in recent years the Indian retail sector has seen major changes with the emergence of modern retail formats such as supermarkets and shopping malls in urban centres all over the country. Managers should therefore continue to invest in improving the store layouts, as it would allow shoppers to spend more time in stores and browse the merchandise, which may trigger impulsive urges (Beatty and Ferrell 1998). Retailers should not ignore other elements like employees, music and lighting since shoppers evaluate the store's environment in gestalt terms. If budgets are a constraint, they may focus on layout first. 
Interestingly, store environment (0.26) had a much higher effect on impulse buying than the personality variables, IBT and SET put together $(0.16)$. This is welcome news to managers since all the elements of the store environment are under their control. Anecdotal evidence suggests that most retailers in developing countries try and cut corners in an effort to cut costs. Many supermarkets, even those owned by big business houses, switch off the airconditioning from time to time have employees that are at best indifferent, if not downright discourteous and rude and have long checkout times (Sridharan, 2005). However, we show that this cost cutting may be at the cost of profitable impulse purchases; and even have an adverse impact on patronage (Baker et al., 2002) and loyalty (Sirgy and Samli, 1985). Hence, retailers have to pay much more attention to the store environment and strive to improve its various elements on an ongoing basis.

In view of the importance of store environment, even traditional "mom and pop" stores have started investing in additional store space and better layouts (Business line 2008), possibly realizing that by doing so, they would be gaining immediate and profitable impulse buying, as also long-term loyalty. Big FMCG companies like Hindustan Unilever (the Indian arm of Unilever) are investing in upgrading the stores to give shoppers a better experience. Foreign retailers such as Wal-Mart and Carrefour who are looking at entering the developing markets may also take note of our findings. They may be tempted to follow the strategies of some local retailers and cut costs by not investing enough in the antecedents of store environment. Doing so may mean loss of profitable impulse purchases. Hence, they probably need to also invest in the various elements of store environment, as the gain due to impulse purchases may well be higher than the costs incurred in doing so.

Just because we did not find support for H7, it does not follow that managers can ignore shoppers' negative affect. In other words, it does not mean that shoppers' negative affect is unimportant. This is because of two reasons. First, as explained in the discussion 
section, this result may be an artifact of our (like Beatty and Ferrell 1998) not being to disentangle pre-existing negative affect from store-induced negative affect. Second, even if there is no significant negative relationship between negative affect and impulse buying, there is clearly a negative relationship between negative affect and patronage and loyalty (Huddleston, Whipple, and VanAuken, 2004). Hence, retailers must ensure that their strategies do not lead to shoppers' negative affect.

\section{LIMITATIONS AND FUTURE RESEARCH}

While our research has valuable contributions, it also has some limitations. First, it did not consider the effect of other individual characteristics such as self-monitoring, which may affect impulse buying and in-store browsing (Luo 2005, Sharma et al., 2010a, 2010b).

Second, we used a survey design with elements of store environment as situational variables. Future research may use experimental design to manipulate various environmental cues and study their impact on real impulse buying behavior, and study the impact of other situational variables on impulse buying such as in-store browsing and type of shopping trip.

Third, we do not consider the aesthetics and appearance of a store, and the role of instore promotions, which may also affect impulse buying. Fourth, due to operational constraints, our research used grocery shopping as a setting for our study, and found significant results despite a relatively lower degree of impulse buying in this category. Future research may explore the influence of store environment in others retail categories such as personal products, apparel, accessories, and personal electronics (Jones et al., 2003)

Finally, recent research links impulse buying to another hedonic purchase behavior, namely variety seeking behavior, showing that both these behaviors have a lot in common, including some antecedents (e.g., consumer impulsiveness and optimum stimulation level) driving both impulse buying as well as variety seeking (Sharma et al. 2010a, 2010b). If so, 
given that store environment drives impulse buying, could it drive variety seeking behavior as well? Future research could address this issue as well.

\section{REFERENCES}

Aghazadeh, S. M. (2005), "Layout strategies for retail operations: A case study," Management Research News, Vol.28 No.10, pp.31-46.

Anderson, J. C. and Gerbing D. W. (1988), "Structural equation modeling in practice: A review and recommended two-step approach," Psychological Bulletin, Vol.103 No.3, pp.41123.

Ang, S. H., Leong, S. M. and Lim, J. (1997), "The mediating influence of pleasure and arousal on layout and signage effects: Comparing more and less customized retail services," Journal of Retailing and Consumer Services, Vol.4 No.1, pp.13-24.

Areni, C. S. and Kim, D. (1994), "The influence of in-store lighting on consumers' examination of merchandise in a wine store," International Journal of Research in Marketing, Vol.11 No.2, pp.117-25.

Ashley, C., Ligas, M., Chaudhuri, A., (2010), "Can hedonic store environments help retailers overcome low store accessibility? The Journal of Marketing Theory and Practice, Vol. 18, No. 3, pp.249 - 62

Babin, B. J. and Attaway, J. S. (2000), "Atmospheric affect as a tool for creating value and gaining share of customer," Journal of Business Research, Vol.49 No.2, pp.91-99.

Babin, B. J., Darden, W. R. and Griffin, M. (1994), "Work and/or fun: Measuring hedonic and utilitarian shopping value," Journal of Consumer Research, Vol.20 No.4, pp.644-56.

Baker, J., Grewal, D. and Parasuraman, A. (1994), "The influence of store environment on quality inferences and store image," Journal of Academy of Marketing Science, Vol.22 No.4, pp.328-39.

Baker, J., Parasuraman, A., Grewal, D. and Voss, G. B. (2002), "The influence of multiple store environment cues on perceived merchandise value and patronage intentions," Journal of Marketing, Vol.66 No.2, pp.120-41.

Baumeister, R. F. (2002), "Yielding to temptation: Self-control failure, impulsive purchasing, and consumer behavior," Journal of Consumer Research, Vol.28 No 4, pp.670-76.

Beatty, S. E. and Ferrell, M. E. (1998), "Impulse buying: Modeling its precursors," Journal of Retailing, Vol.74 No.2, pp.169-91.

Bellenger, D. N. and Korgaonkar, P. K. (1980), "Profiling the recreational shopper," Journal of Retailing, Vol.56 No.3, pp.77-79. 
Beverland, M., Lim, E.A.C., Morrison, M. and Terziovski, M. (2006), "In-store music and consumer-brand relationships: Relational transformation following experiences of (mis) fit," Journal of Business Research, Vol.59 No.9, pp.982-89.

Bitner, M. J. (1990), "Evaluating service encounters: The effects of physical surroundings and employee responses", Journal of Marketing, Vol.54 No.2, pp.69-82.

Bitner, M. J. (1992), "Servicescapes: The impact of physical surroundings on customers and employees," Journal of Marketing, Vol.56 No.2, pp.57-71.

Bruner II, G. C. (1990), "Music, mood, and marketing," Journal of Marketing, Vol.54 No.4, pp.94-104.

Business Line (2008), “Chennai's flourishing kiranas," available at [http://www.thehindubusinessline.com/catalyst/2008/05/29/stories/200805295002010.htm]: (Accessed Jun 15, 2010)

Chandon, P., Hutchinson, J.W., Bradlow, E.T and Young, S.H. (2009) "Does in-store marketing work? Effects of the number and position of shelf facings on brand attention and evaluation at the point of purchase", Journal of Marketing, Vol. 73, pp.1-17

Chebat, J. C. and Michon, R. (2003), "Impact of ambient odors on mall shoppers' emotions, cognition, and spending: A test of competitive causal theories," Journal of Business Research, Vol.56 No.7, pp.529-39.

Collins-Dodd, C. and Lindley, T. (2003), "Store brands and retail differentiation: The influence of store image and store brand attitude on store own brand perceptions," Journal of Retailing and Consumer Services, Vol.10 No.6, pp.345-52.

Coltman, T., Devinney, T. M., Midgley, D. F. and Venaik, S. (2008), "Formative versus reflective measurement models: Two applications of formative measurement," Journal of Business Research, Vol.61 No.12, pp.1250-62.

Crosby, L. A., Evans, K. R. and Cowles, D. (1990), "Relationship quality in services selling: An interpersonal influence perspective," Journal of Marketing, Vol.54 No.3, pp.68-81.

Darden, W. R., Erdem, O. and. Darden, D. K. (1983), "A Comparison and Test of Three Causal Models of Patronage Intentions," in William R. Darden and Robert F. Lusch,(Eds.), Patronage Behavior and Retail Management, New York, NY: North-Holland, pp.29-43.

D'Astous, A. (2000), "Irritating aspects of the shopping environment," Journal of Business Research, Vol.49 No.1, pp.149-56.

Diamantopoulos, A. and Winklhofer, H. M. (2001), "Index construction with formative indicators: An alternative to scale development," Journal of Marketing Research, Vol.38 No.2, 269-77.

Dickson, J. and Albaum, G. (1977), "A method for developing tailor-made semantic differentials for specific marketing content areas," Journal of Marketing Research, Vol.14 No.1, pp.87-91. 
Dillman, Don A. (1994). How to conduct your own survey. New York: John Wiley \& Sons.

Donovan, R. J., Rossiter, J. R., Marcoolyn, G. and Nesdale, A. (1994), "Store atmosphere and purchasing behavior," Journal of Retailing, Vol.70 No.3, pp.283-94.

Dholakia, U. M. (2000) "Temptation and resistance: An integrated model of consumption impulse formation and enactment," Psychology and Marketing, Vol.17 No.11, pp.955-982.

Dubé, L. and Morin, S. (2001), "Background music pleasure and store evaluation: Intensity effects and psychological mechanisms," Journal of Business Research, Vol. 54 No.2, pp.10713.

Eroglu, S. A. and Machleit, K. A. (1993), "Atmospheric factors in the retail environment: sights, sounds and smells", McAlister, L. and Rothschild, M.L. (Eds.), Advances in Consumer Research, Vol.20, Provo, UT: Association for Consumer Research, pp.34.

Fornell, C. and Larcker, D.F. (1981), "Evaluating structural equation models with unobservable variables and measurement error", Journal of Marketing Research, Vol. 18, pp. $39-50$.

Gardner, M. P. (1985), "Mood states and consumer behavior: A critical review," Journal of Consumer Research, Vol.12 No.3, pp.281-00.

Garlin, F. V. and Owen, K. (2006), "Setting the tone with the tune: A meta-analytic review of the effects of background music in retail settings," Journal of Business Research, Vol.59 No.6, pp.755-64.

Ghani, U. and Kamal, Y. (2010), "The impact of in-store stimuli on the impulse purchase behaviour of consumers in Pakistan", The Interdisciplinary Journal of Contemporary Research in Business, Vol. 8 No. 2, pp.155-60.

Ghosh, P., Tripathi, V., and Kumar, A. "Customer expectations of store attributes: A study of organized retail outlets in India” Journal of Retail Leisure Property, Vol. 9 No. 1, pp.75-87

Guenzi, P., Johnson, M.D., Castaldo, S. (2009) "A comprehensive model of customer trust in two retail stores", Journal of Service Management, Vol. 20 No. 3, pp.290 - 316

Harman, H. H. (1967). Modern factor analysis (2nd ed.). Chicago: University of Chicago Press.

Hu, H. and Jasper, C. J. (2006), "Social cues in the store environment and their impacts on store image," International Journal of Retail Distribution Management, Vol.34 No.1, pp.2548 .

Hu, L. and Bentler, P. M. (1999), "Cut off criteria for fit indexes in covariance structure analysis: Conventional criteria versus new alternatives," Structural Equation Modeling, Vol.6 No.1, pp.1-55. 
Huddleston, P., Whipple, J., VanAuken, A.(2004), "Food store loyalty: Application of a consumer loyalty framework," Journal of Targeting, Measurement and Analysis for Marketing, Vol. 12, No. 3, pp. 213-30.

Iacobucci, D., Saldanha,N. and Deng, X.(2007), "A meditation on mediation: Evidence that structural equations models perform better than regressions", Journal Of Consumer Psychology, Vol. 17 No. 2, pp.140-54

Jarvis, C. B., Mackenzie, S. B., Podsakoff, P. M., Mick, G. M. and Bearden, W. O. (2003), "A critical review of construct indicators and measurement model misspecification in marketing and consumer research," Journal of Consumer Research, Vol.30 No.2, pp.199218.

Jones, M. A. (1999), "Entertaining shopping experiences: An exploratory investigation," Journal of Retailing and Consumer Services, Vol.6 No.3, pp.129-39.

Jones, M. A., Reynolds, K. A., Weun, S. and Beatty, S. E. (2003), "The product-specific nature of impulse buying tendency," Journal of Business Research, Vol.56 No.7, pp.505-11.

Kacen, J. J. and Lee, J. A. (2002), "The influence of culture on consumer impulsive buying behavior," Journal of Consumer Psychology, Vol.12 No.2, pp.163-76.

Karmali, N. (2007), "Meet Coke's next boss"? An interview with Muhtar Kent, CEO - Coca Cola, Business India, Dec 18.

Kline, Rex B. (1998), Principles and Practice of Structural Equation Modeling, Guilford Press, New York, NY.

Luo, X. (2005), "How does shopping with others influence impulsive purchasing?" Journal of Consumer Psychology, Vol.15 No.4, pp.288-94.

Machleit, K. A. and Eroglu, S.A. (2000), "Describing and measuring emotional response to shopping experience,” Journal of Business Research, Vol.49 No.2, pp.101-11.

Mattila, A. S. and Enz, C. A. (2002), "The role of emotions in service encounter," Journal of Service Research, Vol.4 No.4, pp.268-77.

Mattila, A. S. and Wirtz, J. (2001) "Congruency of scent and music as a driver of in-store evaluations and behavior", Journal of Retailing, Vol.77 No.2, pp.273-89.

Mick, D.G. and DeMoss, M. (1990), "Self-gifts: Phenomenological insights from four contexts," Journal of Consumer Research, Vol.17 No.3, pp.322-32.

Milliman, R. E. (1982), "Using background music to affect the behavior of supermarket shoppers," Journal of Marketing, Vol.46 No.3, pp.86-91.

Milliman, R. E. (1986), "The influence of background music on the behavior of restaurant patrons," Journal of Consumer Research, Vol.13 No.2, pp.286-89. 
Mishra, A., Mishra, H., and Masters, T., (2012), "The Influence of bite-size on quantity of food consumed: A field study", Journal of Consumer Research, (Forthcoming).

Morin, M. and Chebat, J. C. (2005), "Person - place congruency: The interactive effects of shopper style and atmospherics on consumer expenditure," Journal of Service Research, Vol.8 No.2, pp.181-91.

Morrison, M., Gan, S. Dubelaar, C. Oppewal, H. (2011) "In-store music and aroma influences on shopper behaviour and satisfaction", Journal of Business Research, Vol. 64 No. 6, pp. 558-64.

Oliver, R. L. and Swan, J. E. (1989), "Consumer perceptions of interpersonal equity and satisfaction in transactions: A field survey approach," Journal of Marketing, Vol.53 No.2, pp.21-35.

Podsakoff, P. M., MacKenzie, S. B., Lee, J. Y. and Podsakoff, N. P. (2003), "Common method biases in behavioral research: A critical review of the literature and recommended remedies," Journal of Applied Psychology, Vol.88 No.5, pp.879-903.

Peck, J. and Childers, T. L. (2006), "If I touch it I have to have it: Individual and environmental influences on impulse purchasing," Journal of Business Research, Vol.59 No.6, pp.765-69.

Ramanathan,S and Menon,G.(2006), "Time-varying effects of chronic hedonic goals on impulsive behavior", Journal of Marketing Research, Vol. 18 (November), pp.628-41

Rook, D. W. (1987), "The buying impulse," Journal of Consumer Research, Vol.14 No.2, pp.189-99.

Rook, D.W. and R.J. Fisher (1995), "Normative influences on impulsive buying behavior," Journal of consumer research, Vol. 22 (December), pp. 305-13.

Russell, J.A. and A. Mehrabian (1976), "Environmental variables in consumer research. Journal of Consumer Research, Vol.3, pp.62-63.

Semeijn, J., van Riel, A.C.R. and Ambrosini, A. B. (2004), "Consumer evaluations of store brands: Effects of store image and product attributes," Journal of Retailing and Consumer Services, Vol.11 No.4, pp. 247-58.

Sharma, A. and Stafford, T. F. (2000), "The effect of retail atmospherics on customers' perceptions of salespeople and customer persuasion: An empirical investigation," Journal of Business Research, Vol.49 No.2, pp.183-91.

Sharma, P., Sivakumaran, B. and Marshall, R. (2010a), "Impulse buying and variety seeking: A trait-correlates perspective," Journal of Business Research, Vol.63 No.3, pp.276-83.

Sharma, P., Sivakumaran, B. and Marshall, R. (2010b), "Exploring impulse buying and variety seeking by retail shoppers: Towards a common conceptual framework," Journal of Marketing Management, Vol.26 No.5-6, pp.473-94. 
Sherman, E., Mathur, A. and Smith, R. B. (1997), "Store environment and consumer purchase behavior: Mediating role of consumer emotions", Psychology and Marketing, Vol.14 No.4, pp.361-79.

Simonson, I. (1999), "The effect of product assortment on buyer preference," Journal of Retailing, Vol.75 No.3, pp.347-70.

Sirgy, M. J. and Samli, A. C. (1985), "A path analytic model of store loyalty involving selfconcept, store image, geographic loyalty and socio economic status," Journal of the Academy of Marketing Science, Vol.13 No.3, pp.265-91.

Silvera,D.H., Lavack, A. M., Kropp, F. (2008), "Impulse buying: The role of affect, social influence, and subjective wellbeing", Journal of Consumer Marketing, Vol. 25 No. 1, pp.23 33.

Smith, W. (1989), "Trends in retail lighting: An intelligent design approach," International Journal of Retail and Distribution Management, Vol.17 No.5, pp.30-32.

Spies, K., Hesse, F. and Loesch, K. (1997), "Store atmosphere, mood and purchasing behavior," International Journal of Research in Marketing, Vol.14 No.1, pp.1-17.

Sproles, G. B. and Kendall, E. L. (1986), “A methodology for profiling consumers' decisionmaking styles," Journal of Consumer Affairs, Vol.20 No.2, pp.267-79.

Sridharan, A. (2005), "Long and short of Indian retail,", available at http://radventure.blogspot.com/2005/11/long-and-short-of-indian-retail.html (Accessed Aug 20, 2010)

Steel, R.G.D. and Torrie, J.H. (1980), Analysis of covariance, In: Principles and Procedures of Statistics: a Biometrical Approach, pp. 401-437. McGraw-Hill, New York.

Stern, H. (1962), "The significance of impulse buying today," Journal of Marketing, Vol.26 No.2, pp.59-62.

Stilley, K.M., Inman, J.J., and Wakefield, K.K. (2010) "Planning to make unplanned purchases? The role of in-store slack in budget deviation", Journal of Consumer Research, Vol. 37 No.2, pp.264-78.

Summers, T. A. and Hebert, P. A. (2001), "Shedding some light on store atmospherics influence of illumination on consumer behavior," Journal of Business Research, Vol.54 No.2, pp.145-50.

Turley, L. W. and Milliman, R. E. (2000), "Atmospheric effects on shopping behavior: A review of the experimental evidence," Journal of Business Research, Vol.49 No.2, pp.193211.

Tuyet Mai, N., Jung, K., Lantz, G. and Loe, S. G. (2003), "An exploratory investigation into impulse buying behavior in a transitional economy: A study of urban consumers in Vietnam," Journal of International Marketing, Vol.11 No.2, pp.13-35. 
Underhill, P.,(1999), Why We Buy: The Science of Shopping. Simon and Schuster, New York.

Vahie, A. and Paswan, A. (2006). "Private label brand image: its relationship with store image and national brand," International Journal of Retail and Distribution Management, Vol.34 No.1, pp.67-84.

Ward, J. C., Mary J. B. and Barnes, J. (1992), "Measuring the proto typicality and meaning of retail environments," Journal of Retailing, Vol.68 No.2, pp.194-220.

Watson, D., Clark, L. and Tellegen, A. (1985), "Toward a consensual structure of Mood", Psychological Bulletin, Vol. 98, pp.219-35

Watson, D., Clark, L. and Tellegen, A. (1988), "Development and validation of brief measures of positive and negative affect: The PANAS scales," Journal of Personality and Social Psychology, Vol.54 No.6, pp.1063-70.

Westbrook, R. A. and Oliver, R. L. (1991), "The dimensionality of consumption emotion patterns and consumer satisfaction," Journal of Consumer Research, Vol.18 No.1, pp.84-91.

Weun, S., Jones, M. A. and Beatty, S. E. (1998), "The development and validation of the impulse buying tendency scale," Psychological Reports Vol.82 No.3, pp.1123-33.

Wheatley, J. J. and Chiu J. S. Y. (1977), "The effects of price, store image, and product and respondent characteristics on perceptions of quality," Journal of Marketing Research, Vol.14 No.2, pp.181-86.

Wheaton, B., Muthen, B. Alwin, D. F. and Summers, G. F. (1977), "Assessing reliability and stability in panel models," Heise D. R. (Ed.), Sociological methodology, Jossey-Bass, San Francisco, CA.

Yalch, R. and Spangenberg, E. (1990), "Effects of store music on shopping behavior," The Journal of Services Marketing, Vol.4 No.1, pp.31- 39.

Yoo, C., Park, J. and. MacInnis, D. J. (1998), "Effects of store characteristics and in-store emotional experiences on store attitude," Journal of Business Research, Vol.42 No.3, pp.253-63.

Youn, S. and Faber, R. J. (2000), "Impulse buying: It's relation to personality traits and cues," Fisher, S.J. and R.J. (Eds.), Advances in Consumer Research. Vol.27, Provo, UT: Association for Consumer Research, 179-85.

Zhou, L. and Wong, A. (2003), "Consumer impulse buying and in-store stimuli in Chinese supermarkets,” Journal of International Consumer Marketing, Vol.16 No.2, pp.37-53. 
Figure 1 - Conceptual Model (with Hypotheses)

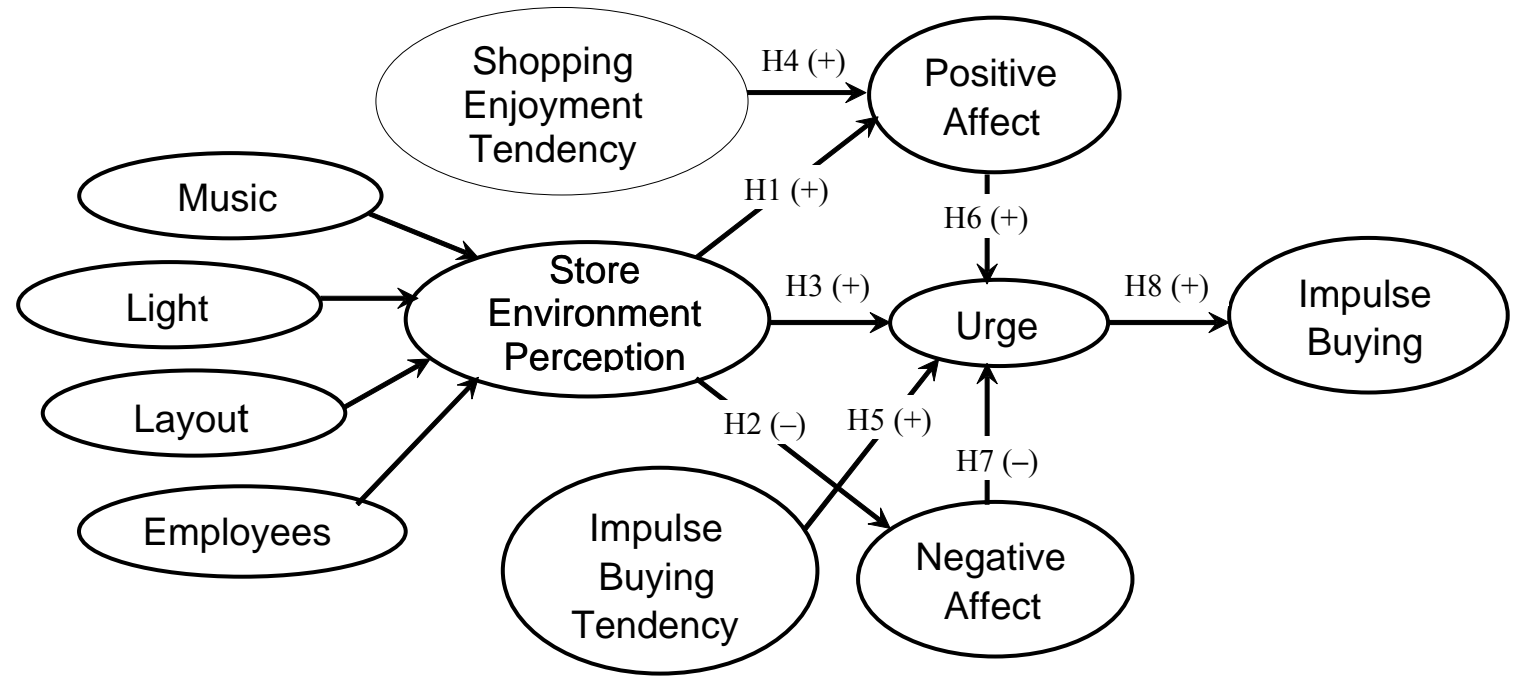

Figure 2 - Structural Model (with Direct \& Indirect Effects)

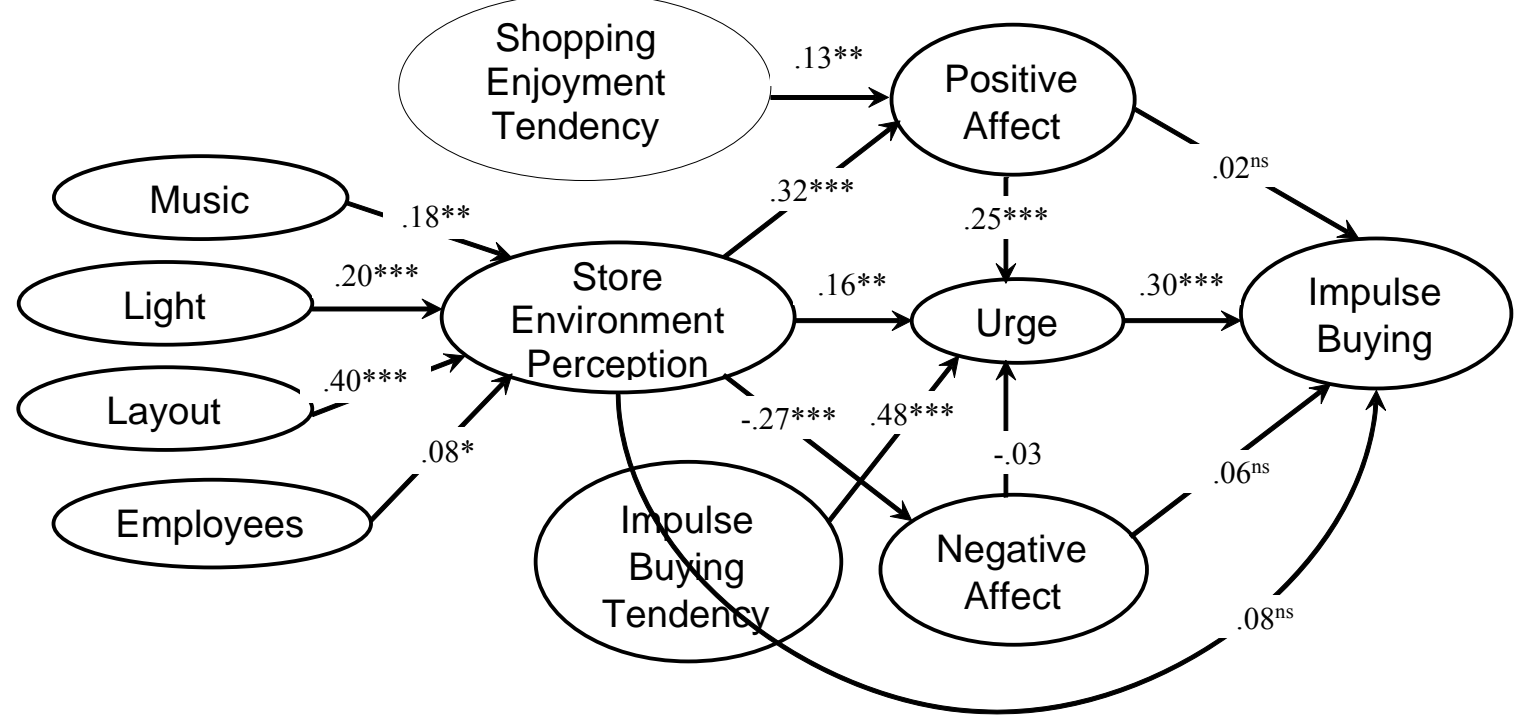


Table 1 - Scale Summary

\begin{tabular}{|c|c|c|c|c|}
\hline Scale Items & $\begin{array}{c}\text { Factor } \\
\text { loadings } \\
(\lambda) \\
\end{array}$ & $\begin{array}{c}\text { Item-total } \\
\text { Correlation } \\
(\alpha) \\
\end{array}$ & $\begin{array}{c}\text { Mean } \\
(\mathrm{M})\end{array}$ & $\begin{array}{l}\text { Std } \\
\text { Dev } \\
\text { (SD) } \\
\end{array}$ \\
\hline Music (Morin and Chebat 2005) & & & 2.63 & 1.06 \\
\hline 1. The store had pleasant music & .92 & .56 & 2.89 & 1.16 \\
\hline 2. The store had appropriate music & .92 & .53 & 2.71 & 1.09 \\
\hline 3. The store had terrible music * & .65 & .46 & 2.30 & 1.03 \\
\hline $\begin{array}{l}\text { Light (Smith 1989, Areni and Kim 1994, Summers and } \\
\text { Hebert 2001) }\end{array}$ & & & $\mathbf{3 . 5 3}$ & 0.68 \\
\hline 1. The store is well- lit & .70 & .49 & 3.51 & .85 \\
\hline 2. The store is correctly-lit (Neither too bright nor dull) & .81 & .54 & 3.45 & .84 \\
\hline 3. Lighting in the store is pleasant & .70 & .39 & 3.64 & .80 \\
\hline Employees (Dickson and Albaum 1977) & & & 3.56 & .77 \\
\hline 1. The store had knowledgeable employees & .77 & 62 & 3.48 & .89 \\
\hline 2. The store had friendly employees & .87 & .75 & 3.54 & .88 \\
\hline 3. The store had helpful employees & .87 & .74 & 3.65 & .89 \\
\hline Layout (Dickson and Albaum 1977) & & & 3.63 & .74 \\
\hline 1. It was easy to move about in the store & .75 & .56 & 3.70 & .82 \\
\hline 2. It was easy to locate products/merchandise in the store & .83 & .64 & 3.62 & .85 \\
\hline 3. The store had attractive displays & .70 & .46 & 3.57 & .83 \\
\hline Positive Affect (Watson et al. 1988) & & & 3.25 & .72 \\
\hline 1. I felt excited on this shopping trip & .86 & .66 & 3.21 & .87 \\
\hline 2. I felt enthusiastic while shopping today & .87 & .72 & 3.19 & .86 \\
\hline 3. I felt happy during this shopping trip & .71 & .54 & 3.33 & .81 \\
\hline Negative Affect (Watson et al. 1988) & & & 2.32 & .80 \\
\hline 1. I felt bored on this shopping trip & .85 & 68 & 2.42 & .93 \\
\hline 2. I felt lethargic while shopping today & .81 & 67 & 2.34 & .94 \\
\hline 3. I felt upset during this shopping trip & .87 & .72 & 2.18 & .91 \\
\hline Urge (Beatty and Ferrell 1998) & & & 3.06 & .93 \\
\hline 1. I experienced many sudden urges to buy unplanned items & .80 & .59 & 3.14 & 1.04 \\
\hline 2. I was tempted to buy many items that were not on my list & .79 & .49 & 3.10 & 1.04 \\
\hline 3. I experienced no sudden urges to buy unplanned items * & .68 & .44 & 2.95 & 1.02 \\
\hline Impulse Buying Tendency (Weun, Jones, and Beatty, 1998) & & & 3.12 & .69 \\
\hline 1. I avoid buying things that are not on my shopping list * & .66 & .44 & 3.27 & .90 \\
\hline $\begin{array}{l}\text { 2. When I go shopping, I buy things that I had not intended } \\
\text { buying }\end{array}$ & .70 & .47 & 3.10 & .99 \\
\hline 3. I am a person who makes unplanned purchases & .71 & .48 & 3.19 & .95 \\
\hline $\begin{array}{l}\text { 4. When I see something that really interests me, I buy it } \\
\text { without considering the consequences }\end{array}$ & .61 & .40 & 3.22 & .95 \\
\hline 5. It is fun to buy spontaneously & .73 & .49 & 2.83 & .97 \\
\hline Shopping Enjoyment Tendency (Sproles and Kendall 1986) & & & 3.17 & .86 \\
\hline 1. Shopping is one of my favorite activities & .91 & .65 & 3.60 & .92 \\
\hline 2. I find shopping an enjoyable experience & .89 & .63 & 3.62 & .88 \\
\hline 3. Shopping in stores is a waste of time $*$ & .67 & .54 & 2.28 & .92 \\
\hline
\end{tabular}

* Reverse coded items 
Table 2 - Frequency Distribution of Impulse Purchases

\begin{tabular}{cccc}
\hline $\begin{array}{c}\text { Number of } \\
\text { Impulse } \\
\text { Purchases }\end{array}$ & $\begin{array}{c}\text { Frequency } \\
\text { (No.of } \\
\text { participants) }\end{array}$ & $\begin{array}{c}\text { Percentage } \\
(\%)\end{array}$ & $\begin{array}{c}\text { Cumulative } \\
\text { Percentage (\%) }\end{array}$ \\
\hline 0 & 421 & 58.5 & 58.5 \\
1 & 175 & 24.3 & 82.8 \\
2 & 54 & 7.5 & 90.3 \\
3 & 32 & 4.4 & 94.7 \\
4 & 15 & 2.1 & 96.8 \\
5 & 11 & 1.5 & 98.3 \\
6 & 6 & .8 & 99.2 \\
7 & 2 & .3 & 99.4 \\
8 & 4 & .6 & 100.0 \\
\hline Total & 720 & 100.0 & \\
\hline
\end{tabular}

Table 3 - Hypotheses and Results

\begin{tabular}{lccc}
\hline Hypotheses & $\begin{array}{c}\text { Path } \\
\text { Coefficient }\end{array}$ & t-value & Result \\
\hline H1: Store Environment Perception $\rightarrow$ Positive Affect & $.31 * * *$ & 5.23 & Supported \\
H2: Store Environment Perception $\rightarrow$ Negative Affect & $-.29 * * *$ & -3.28 & Supported \\
H3: Store Environment Perception $\rightarrow$ Urge To Buy Impulsively & $.15 * *$ & 2.89 & Supported \\
\hline H4: Shopping Enjoyment Tendency $\rightarrow$ Positive Affect & $.11 * *$ & 2.60 & Supported \\
H5: Impulse Buying Tendency $\rightarrow$ Urge To Buy Impulsively & $.45 * * *$ & 6.98 & Supported \\
H6: Positive Affect $\rightarrow$ Urge To Buy Impulsively & $.27 * * *$ & 3.17 & Supported \\
H7: Negative Affect $\rightarrow$ Urge To Buy Impulsively & -.01 & -.22 & Not Supported \\
H8: Urge To Buy Impulsively $\rightarrow$ Impulse Buying & $.27 * * *$ & 3.21 & Supported \\
\hline
\end{tabular}


Table 4 - Correlations Matrix

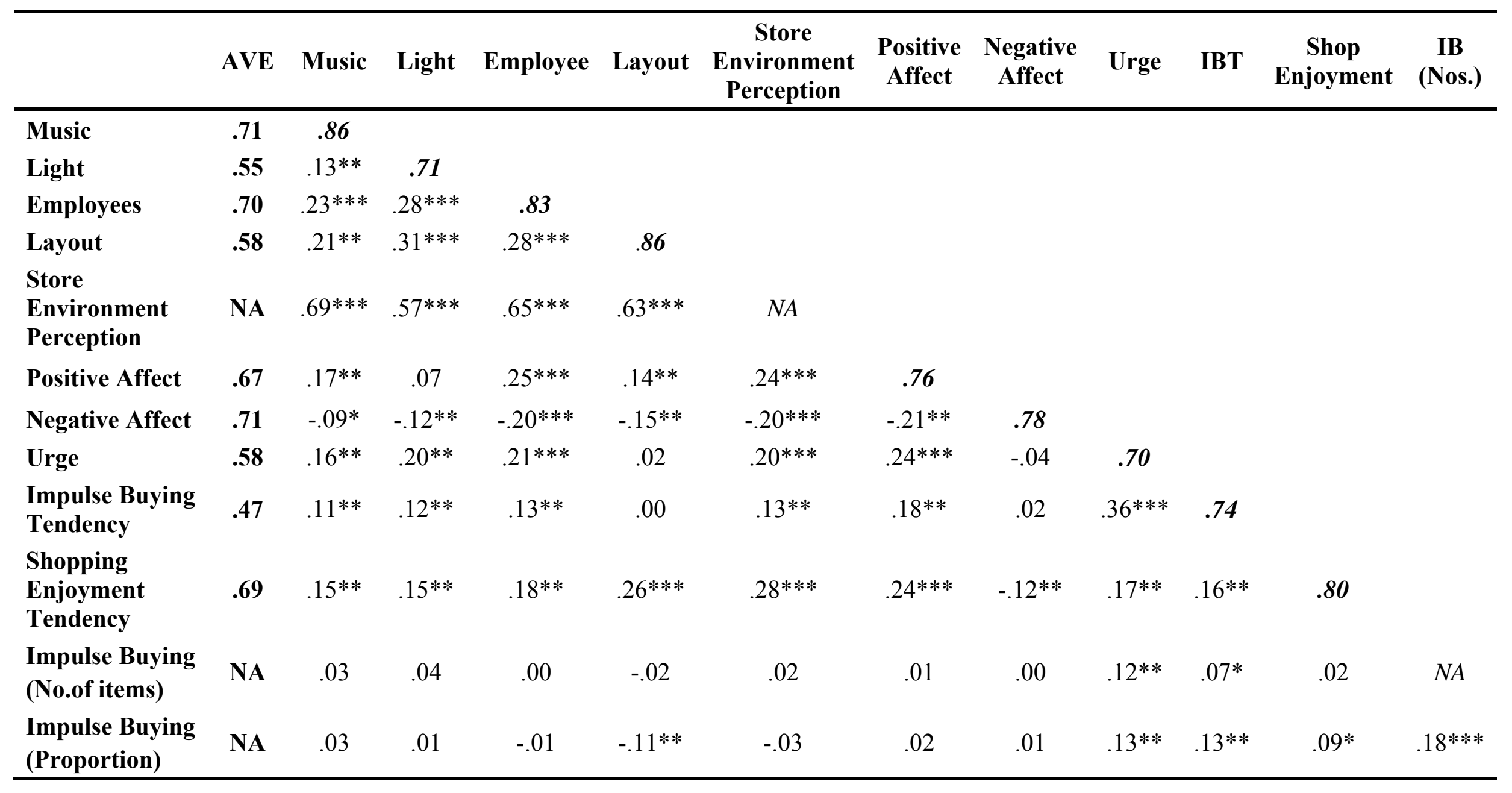

${ }^{*} p<.05 ;{ }^{* *} p<.01 ;{ }^{* * *} p<.001$ (Note: Composite Reliabilities for all the scales are reported in the diagonal) AVE: Average Variance Extracted 
Table 5 - Direct and Indirect Effects on Impulse Buying

\begin{tabular}{|l|c|c|c|}
\hline Predictor & $\begin{array}{c}\text { Direct } \\
\text { Effect }\end{array}$ & $\begin{array}{c}\text { Indirect } \\
\text { Effect }\end{array}$ & Total Effect \\
\hline Light & - & 0.029 & 0.029 \\
\hline Music & - & -0.26 & 0.02 \\
\hline Layout & - & 0.058 & 0.058 \\
\hline Employee & - & 0.012 & 0.012 \\
\hline Store Environment Perception & 0.08 & 0.065 & 0.145 \\
\hline Shopping Enjoyment Tendency & - & 0.012 & 0.012 \\
\hline Impulse Buying Tendency & - & 0.144 & 0.144 \\
\hline Positive Affect & 0.02 & 0.08 & 0.10 \\
\hline Negative Affect & 0.06 & -0.009 & 0.051 \\
\hline Urge & .30 & - & .30 \\
\hline
\end{tabular}

